Original Articles

\title{
Aboriginal Rules: The Black History of Australian Football
}

ArticleDoiMeta

DOI: $10.1080 / 09523367.2015 .1124861$

Sean Gorman ${ }^{a^{*}}$, Barry Judd ${ }^{\mathrm{b}}$, Keir Reeves ${ }^{\mathrm{c}}$, Gary Osmond ${ }^{\mathrm{d}}$, Matthew Klugman ${ }^{\mathrm{e}}$ \& Gavan McCarthy ${ }^{f}$

\section{Abstract}

This paper is interested in the significance of Australian football to the Aboriginal and Torres Strait Islander people of Australia. In particular, this paper is interested in the cultural power of football and how it has foregrounded the struggle and highlighted the contribution that Indigenous people have made to the national football code of Australia. This paper also discusses key moments in Indigenous football history in Australia. It questions further that a greater understanding of this contribution needs to be more fully explored from a national perspective in order to appreciate Indigenous peoples' contribution to the sport not just in elite competitions but also at a community and grass roots level.

\section{Introduction}

What may have begun as a simple forgetting of other possible views turned under habit and over time into something like a cult of forgetfulness practised on a national scale.

W.E.H. Stanner 1968. ${ }^{1}$

Graham 'Polly' Farmer is regarded as one of the best exponents of Australian Rules football. This was due to his abilities and innovative play that reshaped the game. Specifically, his agility and his long, quick handballs became great attacking manoeuvres that complemented Geelong's potent midfield. ${ }^{2}$ Yet there is a distinct aspect to Farmer's story that many historians and sports journalists do not know about, have forgotten or simply ignore. That is Farmer may never have had this illustrious career, if not for a vital change in Western Australia's labour 
policies in 1952. A Noongar from the south-west of Western Australia, Farmer was 'given up' to the care of Sister Kate's Children's Cottage Home by his mother Eva in 1936 when only a few months old. Farmer spent his entire childhood and nearly all of his teens at Sister Kate's in Perth. ${ }^{3}$ RIDEN0003 It was during his time at Sister Kate's that Farmer developed a reputation as an outstanding junior footballer. However, government policy, specifically that of the Native Welfare Department of Western Australia, dictated that Aboriginal youth at the age of 16 would be sent into the country to work on farms making them a cheap source of unskilled rural labour. ${ }^{4}$ Farmer said at the time "The only thing I did not want to be was farming. ${ }^{5}$

In 1952, the Sunday Times newspaper in Perth rallied support against the official policy, imploring its readership to send in letters of protest against the Government to send Farmer into the hinterland against his will stating, 'it smacks of slavery'.6 Without the newspaper garnering public support that succeeded in overturning this labour policy, Farmer would have been banished to the back blocks of Western Australia and possibly never heard of again. Instead, Farmer was able to use Australian Rules football to gain some degree of social mobility and acceptance in Anglo-Australian society and the chance for economic independence. This was the opposite of many of Farmer's peers at Sister Kate's who were placed on farms as farmhands or domestics and experienced the status of indentured labour until such time as they were released into the community unskilled and without the wages promised to them. ${ }^{7}$

It is worth pausing to note a term like slavery for it signals an engagement with the history of Australia's race-relations that is absent from the histories of Australian Rules football and Australian history generally. This is not to say that race-relations are not mentioned in broader histories of the game, but rather that they are never a site for investigation. Instead, there are intimations that something beyond sport might be at stake, but that 'thing' is never explained, or perhaps simply taken for granted. For example, in Leonie Sandercock and Ian Turner's pioneering, Up Where, Cazaly? they note in passing that Australian Rules football might 'help members of disadvantaged groups to find a way up the social ladder; thus, playing for Fitzroy was an early step in Aboriginal Doug Nicholls' climb to knighthood and the governorship of South Australia'.8RIDEN0008 Despite the celebrated football lives of Nicholls and Farmer what perhaps now needs to take place in Australian sporting history is a greater exploration of the contribution Indigenous Australians have made over time to Australia's indigenous game. This is suggested in order to frame in a more holistic way the nature of that contribution over time but also to commence a retelling that will incorporate Indigenous Australian stories and voices that is long overdue.

More recent histories of Australian Rules football have devoted some pages to chronicling the way Indigenous players in the Australian Football 
League (AFL) publicly responded to racial abuse from opponents and spectators in the 1990s - charting the move from Nicky Winmar's famed gesture in 1993 to Michael Long's 1995 demand that the AFL act against the on-field vilification that Indigenous players were experiencing at the time. ${ }^{9}$ Nevertheless, while these accounts draw on the history of Australia's race-relations to contextualize the activism of Winmar, Long and others, they do not ask what this activism might tell us of what it has meant to be an Indigenous AFL player in any given era, and also what meaning Australian football has had and continues to have over time for Indigenous Australians. In this respect, this paper is timely because it demands that Aboriginal participation in Australian Football be seen in ways that extend far beyond the capacity of Aboriginal people to play the sport well.

\section{Influences on the Game}

A revealing element of Aboriginal involvement in Australian football that has generated the greatest interest in broad histories of the game concerns the question of its origins. Indeed, the origins and early development of Australian Rules Football has become a highly contested aspect of Australian sporting history as historians, journalists and some players have grappled over the potential influence that the Djab-wurrung football game commonly known as Marn-grook (meaning ball-foot) played in the evolution of Australian Rules football.10

As several historians have shown, one of the sport's founders Thomas Wentworth Wills spent a great deal of time as a boy with the Djabwurrung people as a boy in the western districts of Victoria during late 1840s. ${ }^{11}$ This country was part of the Australia frontier at the limits of Anglo-Australian 'settlement' where 'settler' and 'native' often lived at close quarters and sometimes developed intimate and long-standing personal relationships. It was in this context that Wills played Djabwurrung games and learned to speak their language and to sing their traditional songs as a child. ${ }^{22}$ It poses a greater question as to whether these formative experiences had any bearing on Wills and influenced the origins of the Australian game.

Jim Poulter and Martin Flanagan have argued that Wills was most likely influenced by the Djab-wurrung games, and that this influence potentially shaped the early development of Australian Rules football. ${ }^{3}$ RIDEN0013 A number of historians of the game have countered that there is no written document of evidence, and that the initial rules of Australian Rules football were more aligned to the British versions of football from the same period. Hibbins went further in claiming that possible Indigenous influences are a 'seductive myth'. ${ }^{14}$ Yet as Cazaly noted, in an article notably subtitled 'Football's History Wars', these historians were relying on sources drawn exclusively from the colonial archive and therefore reflected an exclusively colonial remembrance of the past. ${ }^{15} 5$ Responding to the furore that Cazaly's piece generated, Judd noted that Cazaly had pointed to the limits 
of these histories that reconstructed a particular version of the past. Judd stated:

It is a colonial past that history is able to reconstruct, a past that says little or nothing about Indigenous experience or Indigenous remembrance of that same past carried into the present from the other side of the colonial frontier. ${ }^{16}$

At issue then, are questions of historiography, of voices, evidence and sources and our relationship to them, along with the questions that are asked, the areas of expertise that are brought to bear, and the partiality of the answers that are given. But the intensity of the debate - the investment of considerable energy and emotion - points to the importance that the putative origins of Australian Rules football hold for both Indigenous and non-Indigenous Australians.

\section{A Game for All}

This importance of Australian Rules football to the social and cultural life of many Indigenous Australian communities is much discussed but surprisingly under-researched. General references abound and media sound bites strongly allude to the long-standing centrality of the game to Indigenous communities across the country. This extends to Indigenous players and teams from the elite AFL competition, to semi-professional State and Territory leagues, to the remote and regional leagues that are frequently a lifeblood of rural Australia. This is perhaps best evidenced in the proliferation of themed Indigenous rounds occurring in the elite AFL, second-tier competitions like the WAFL and country leagues. As football journalist John Harms alludes to in the AFL's sesquicentenary book, The Australian Game of Football:

I felt the soul of footy when I went to an Aboriginal communities football carnival at Wanarn $100 \mathrm{~km}$ west of the NT-WA border ... This was the game played purely. For the love of it. Without any of the trappings of commerce or media. This was the heart of football. ${ }^{17}$

Indeed, the general picture is of 'a game' that has ceased to be 'just' a sport and has become instead a social, political, cultural, and economic institution that shapes both daily and seasonal lives and much of Australia's engagement with our complex history of race-relations. ${ }^{18}$

But this general position prompts bigger questions. For example, what has been the nature of Indigenous footballers' emergence and how can this be charted as part of the national narrative to provide a deeper context for that development to be understood? For Godwell, sport provides a crucial field of analysis that enables us to see how Australia as a society works when it comes to issues of race, identity and discrimination. ${ }^{19}$ Godwell critically engages with the discourses surrounding sport and looks at the 'deeper philosophical insights into celebrated human and/or national character' in the world of sport. ${ }^{20}$ It is these deeper insights regarding Indigenous engagement with Australian football that deserve a more nuanced and sophisticated analysis because it is felt that for too long they 
have been ignored.

To extend this out, recently an emerging body of literature has started to provide a window into the importance of Australian Rules football for Indigenous Australians by charting the stories, struggles, and triumphs of individual Indigenous Australian Rules footballers. ${ }^{21}$ What is still missing, however, is a comparative analysis of the way Australian Rules football has been a richly complex site of agency and engagement between nonIndigenous Australians and Indigenous Australians around themes of sport, race, and culture. It is our contention that in asking these questions around the agency and structural, social, and cultural pathways of players like 'Polly' Farmer - who by an administrative quirk was able to become the celebrated player he was - that the history of Australian Rules football can provide a stronger lens into the dynamics of Australia's race-relations that remain largely unexplored. In this way, football enables us to look into this 'sport space' and explore notions of engagement, agency, and discrimination as it was experienced differently in various parts of Australia and thus gives a richer narrative into the differing Indigenous worlds, opportunities, and limitations of post-invasion Australia. We do not pretend that by doing this type of history we can offer a simple solution or indeed a 'moral to the story' but we can provide, by way of experience and active cross-cultural research practices, an insight into the nexus of Indigenous experience and Australian football that may unlock other epistemological doors that Indigenous Australians themselves will inform. This paper therefore, takes the spirit of the stories of individual Indigenous footballer pioneers like Doug Nicholls, Syd Jackson, the Krakouer brothers, Nicky Winmar, Michael Long, Adam Goodes and Liam Jurrah so we can reflect on what they might reveal of Australian history beyond the achievements of these remarkable individuals at the elite level and on such hallowed spaces like the MCG.

\section{Pastor Doug: Pioneer of the Game}

It makes sense to discuss Doug Nicholls, for he is emblematic of the way Australian Rules football provided a rare avenue to escape oppressive government interference in the lives of Indigenous Australians and the social and political heights he scaled in his post football career. As Nicholls' story shows regarding Aboriginal people, Australian Football has become deeply significant in their social and political struggle for civil rights, land rights, and the cultural right to remain distinctive peoples within a contemporary Australian nation state dominated by non-Indigenous peoples and values. Yet Nicholls is also unfortunately significant in the way the legacy, tales, and deeds of many significant Indigenous Australian activists have largely fallen out of the popular memory of non-Indigenous Australia. Nicholls' impact on Australia's social, cultural, and political life has been compelling and yet many non-Indigenous high school and undergraduate students have never heard of him in the same way as they have Winmar or Long. 
The story that is told most frequently about Nicholls' football career, concerns the racism he experienced during a pre-season with the Carlton Football Club in 1927 - the Carlton players had never seemed comfortable around him, with some complaining that he 'smelled'.22RIDEN0022 What was Carlton's loss became Fitzroy's gain as Nicholls demonstrated he could play at the top VFL level with 54 games over six years, a state guernsey in 1935 and a third placing in the 1934 Brownlow medal count. This was after establishing himself with the Victorian Football Association (VFA) side Northcote, helping them to a premiership and achieving renown as a brilliant wingman.

What is less known, however, is the great esteem in which many held Nicholls. In 1934, for example, the Argus noted glowingly that 'It is safe to say that a more popular player never wore football boots in Australia', while a 1935 profile in the same paper commented that: 'Doug Nicholls, the Aboriginal footballer who plays for Fitzroy's League team, must be one of the most gentlemanly and most popular sportsmen in Australia. He is a model for any boy to copy'. ${ }^{23}$ That last sentence stands out, 'A model for any boy to copy.' This is notable because it was written in an era when fears of white Australian racial degeneration abounded and lighterskinned Aboriginal children were being stolen from their parents. ${ }^{24}$ To put this into a larger political context just a few years earlier Nicholls' sister had been forcibly taken by police to a home which trained Aboriginal girls to work as domestic servants and prevented them from contacting family members. Yet through his actions on Australian Rules football fields, Doug Nicholls was now seen, via the prism of football, as someone to be emulated. As Indigenous VFL umpire Glenn James recalls:

We'd go to church because Pastor Doug Nicholls would come up to the Church of Christ at Mooroopna and to us he was a cult hero ... I remember him having an enduring fight for his people. For him to keep standing up after being knocked down was amazing. 25

Though he might have been excelling at the settlers' game, Nicholls was not using football as a means to escape or abandon his cultural heritage or his racial roots. Time after time he is quoted as being proud of his heritage. This is shown in another news piece from Albany, a port town in the Great Southern of Western Australia, where Nicholls talks about the way his 'people' pay close attention to his actions by way of wireless and newspaper reports. One can then see the power of his status and how 'mainstream' sporting prowess could be celebrated by the Pan-Indigenous communities and non-Indigenous people alike. ${ }^{26}$

Nicholls also used his public status - celebrity even - to become a strong public advocate for Aboriginal rights. As he noted in an address on the first Day of Mourning held on Australia Day, 1938, protesting the 150th anniversary of colonization: 'The public does not realise what our people have suffered for 150 years ... Put on reserves, with no proper education, how can Aborigines take their place as equals with whites?'. Nicholls 
continued 'now is our chance to have things altered. We must fight our very hardest in this cause. After 150 years our people are still influenced and bossed by white people. I know that we could proudly hold our own with others if given the chance'. ${ }^{27}$

Sport had been like a 'university' for Doug Nicholls and now he began putting his education to work using his powerful agency and social capital to great effect. After retiring from football in 1939, Nicholls became a Church of Christ Minister, dedicating himself to the cause of Australia's Indigenous peoples, presiding over an Aboriginal congregation in Fitzroy, leading the Australian Aborigines' League, and mentoring Aboriginal athletes. His aim was to 'raise all Aborigines throughout the Commonwealth to full Citizen Status and civil equality with whites in Australia'. ${ }^{28}$ This was no small undertaking at the time especially when compared to attitudes 20 years later from an Australian institution, the Australian Women's Weekly in 1957 which read:

You should meet Pastor Douglas Nicholls, of Fitzroy, Melbourne, if you still think the Australian aboriginal is a simple Stone Age man incapable of taking any but the lowliest place in the technological society of the 20th century. 29

It was a revealing start to a glowing portrait, yet a striking reminder of the attitudes that Nicholls had struggled to combat through sport and religion, and speaks of the difficulties experienced by other Indigenous Australians who did not have the status that Nicholls did and yet still had to endure just the same.

\section{Sport, Race, and History}

The history of Australian Football in many ways reflects the Australian national identity and its evolvement over time. Hence, football has a unique style and language that is undeniably Australian. Originating in Melbourne during the height of the 1850s Victorian gold rush the first official match was played between Scotch College and Melbourne Grammar on Richmond paddock next to the Melbourne Cricket Ground (MCG). ${ }^{30}$ As such Australian Football is considered one of the oldest codified football games in the world. Australian historian and novelist, Thomas Keneally, characterized Australian football as Melbourne's (read: Australia's) 'divine frolic' that subsequently spread nationwide. ${ }^{31}$

It is from the game's official origins and its social, cultural, and historical impact that we can commence to see how scholars like Godwell and Tatz have both engaged with the contemporary world of sport, politics, and the everyday to provide us with an academic bridge so as one can more fully understand the scope of its impact. ${ }^{32}$ Tatz does this by looking at specific historical moments as they pertain to indigenous Australians as he appreciates the importance of sport to Australians more generally. Sport and sport history becomes the vehicle so we may come to a better understanding of Indigenous history. Godwell does this by looking at banal moments within sport, especially those racialized acts or comments that 
arise in sport, and how the media often explained them away as being in 'the heat of the moment':

The issue of racism in sport was simplified to a clash of personalities, or maybe just a hot-headed jibe. This tendency understated the seriousness of the issue and distracted from critical conclusion. Accordingly, Pakistani cricketers become unfairly misrepresented as 'whingers'; Aboriginal footballers as players who can't take a ribbing; black basketballers as having 'chips on their shoulders'. ${ }^{33}$

Encapsulating such attitudes and acceptance of racism in sport, ex-AFL legend and Collingwood Football Club premiership captain Tony Shaw is noted as saying, 'It's a business out there. I'd make a racist comment every week if I thought it would help win a game'. ${ }^{34}$ His comment might be understood as being 'of its time' and a measure of how far the code has come in dealing with racial abuse and on-field vilification. However, such comments are instructive as they underline how recently vilification of Indigenous and non-Anglo-Australian players was regularly employed to gain a 'psychological edge'. 35

When we view Australian sports, particularly Australian football, we can gain insight and develop a greater appreciation of the 'bad race-relations' that Gardiner speaks of when we consider the stories of Indigenous and non-Anglo-Australian players in football. ${ }^{36}$ For many Indigenous players, the professional and social odds were stacked against them as often they played as a single Aboriginal player in their team (or league) during the period 1896 to 1981 . What cannot be disputed is that with the coming of the Krakouer brothers, Jim and Phil, and Maurice Rioli to the VFL in 1982 it created massive media interest that changed the landscape at the elite level of the game forever. The Krakouer brothers represented the first time in VFL history that a cohort of Aboriginal players had been specifically recruited simultaneously to provide complementary roles within the North Melbourne team. With Rioli, Richmond fans got to see how great a player he was winning a Norm Smith Medal in a losing grand final side in 1982.

The football landscape that the Krakouers and Rioli revolutionized in the 1980s came after decades of Indigenous participation in elite level football. Albert 'Pompey' Austin from Framlingham mission in south-west Victoria played a single game for Geelong in 1872, debuting against Carlton. ${ }^{37}$ Jimmy Melbourne was the first Aboriginal player to enjoy a sustained playing career in senior football. Melbourne played in the Western Australian Football League (WAFL) between 1900 and 1904, including the 1901 premiership won by West Perth. Joe Johnson, a 55-game defender, who played in Fitzroy's 1904-05 premiership team was the first Aboriginal player to participate in the VFL. In many ways, it was not just Austin, Melbourne or Johnson who can be seen as the Indigenous pioneers of the sport. Indeed, it was the Indigenous players who followed who can be seen as pioneers of anti-racism in the sport. Players such as Sir Douglas 
Nicholls OBE (Fitzroy: 1932-37), Norm McDonald (Essendon: 1947-53), 'Polly' Farmer (Geelong: 1962-67) and Syd Jackson (Carlton: 1969-1976) in many ways popularized and normalized the idea among non-Indigenous people that Australian Football was a game that Aboriginal peoples played and played well. These players were also pioneers in different eras and in a sense they each created a space so other Indigenous players might follow.

The Krakouer brothers and Rioli established themselves quickly as champions in their own right and VFL/AFL recruiters began to look far and wide to try to lure Indigenous players from all over Australia to Melbourne. However, any positive development in the attitude of the elite leagues to Aboriginal players was underpinned by the long-standing racist notion of Aboriginal people as being physical men (read: unthinking and instinctive). Adam Goodes suggested that racial and cultural characteristics developed over 40,000 years of hunting and gathering had fortuitously produced skills and attributes useful in the playing of Australian Football. 38 However, media reportage drawing on racial and cultural stereotypes framed Aboriginal excellence in football as 'black magic'. ${ }^{99}$ This racist narrative of sport framed Indigenous players' 'skills' as 'natural' and provided no recognition of the hours of training and application that they had endured to become elite sportspeople. The emphasis on 'black magic' in Australian Football also brought with it a contradictory situation that was both hostile (from the opposing teams) and celebratory (from fans and members).

These tensions about the place of Aboriginal people in the sport became most clearly apparent with the West Coast Eagles joining the AFL in 1987. The inaugural team included a number of star Aboriginal players: Phil Narkle, Wally Matera and Chris Lewis. This period marked the period of national expansion as the VFL was renamed the AFL in 1990 and the sport attempted to transform itself from a Victorian-centric tradition to a truly national game with clubs located or affiliated with all Australian states. As a result of national expansion and the need to develop the national aspirations of the sport, the 'racial' complexion of the AFL changed rapidly as the number of Aboriginal players in the elite game became a notable feature of the Australian code. In the final decade of the VFL, the 1980s, it was uncommon and perhaps unthinkable to have a cohort of three or four Indigenous players on a team list. Football fans and the media grappled with the status, exposure, and dynamism that Indigenous players brought with them. ${ }^{40}$ Such discussions were often framed in the context of debate about the ability of Aboriginal players to conform to club cultures with their rigid disciplinary regimes and to control their tempers in the face of on-field sledging that was at the time considered a normal part of the sport.

Today, not having a cohort of Indigenous players on a team list would be deemed extraordinary and detrimental to on-field success. The structural 
changes in the sport created a social, sporting, and political context in which questions about race and in particular the place Indigenous people should have in the national game to the forefront of public attention. Such questions were crystallized in 1993, the international year of Indigenous peoples, where Nicky Winmar single-handedly changed the debate around race-relations in Australia. ${ }^{41}$

In Round 4, Winmar, playing for St Kilda, had been subjected to racial taunts by players and supporting of the opposing team, Collingwood, for the duration of a match at Victoria Park, a ground notorious for its hostility to visiting teams. St Kilda won the match, in a rare victory at the venue, in large part due to the standout play of Winmar and Aboriginal teammate Gilbert McAdam. As the final siren sounded the racial abuse from Collingwood supporters continued. Winmar responded by lifting his jumper and pointing to his black skin. The image captured in the Melbourne newspapers became emblematic of the 'unstable position' Indigenous players occupied in Australian Football. This instability was the ambiguous and often hostile perspectives of non-Indigenous people towards Indigenous Australians which had its genesis in federal and state politics designed to keep the two groups separated. ${ }^{42}$ It was on the football field that it was manifestly obvious that the two groups could, and did, come together.

Winmar's stance transcended the realm of sport and football. It was socially, culturally, and politically important as it tapped into a discussion around race, culture, Indigenous people, and national identity that needed to be had. It is the Australian equivalent to the Tommie Smith/John Carlos/Black Power moment of the 1968 Mexico City Olympics. The stance made by Winmar, combined with Michael Long's stance against racism in 1995, has come to define racism in sport in Australia. A champion Essendon player, Long, took issue with on-field racial abuse received from Collingwood opponent Damian Monkhorst. Long challenged this via legal avenues that forced the AFL and the nation, to engage with the issue of racism at many levels. Long's actions and words led to the introduction of Rule 30, which has since become Rule 35, which outlaws racial and religious vilification in Australian Football and represents a concerted legal-based approach by the AFL to change attitudes, not just about Indigenous players, but also about players from 'different' and diverse non-Anglo-Australian backgrounds.

Such stories about Indigenous players reveal the great strength and persistence of them as people and the courage they displayed at times when the social and political odds were stacked very much against them. The breakthroughs that Winmar and Long were able to make in addressing racism in recent decades could not have been achieved without the inroads made by their Aboriginal predecessors in the sport. The story of Graham 'Polly' Farmer, for example, clearly illustrates and defines the struggle for Indigenous social acceptance and its vital importance to the 
national narrative and Australian Football history alike. It also raises the question: How many Indigenous men were lost to the game because the politics and laws at the time controlled them and denied them participation? The sad thing is we will never know.

For Farmer, a member of the AFL Indigenous Team of the Century, this example shows how football played, and continues to play, a critical and influential role in understanding Australian history and the nature of Aboriginal struggle.43 For Aboriginal peoples, until quite recently, Australian Football provided a rare avenue to escape oppressive government interference in their lives, to gain some degree of social acceptance in Anglo-Australian society and the chance for economic independence. For this reason, for many Indigenous communities Australian Football has meaning and a significance that makes it much more than a game. For Aboriginal people, Australian Football has become deeply engaged in their social and political struggle for civil rights, land rights, and the cultural right to remain distinctive peoples within a contemporary Australian nation state dominated by non-Indigenous peoples, values, and laws.

\section{Where To from Here?}

While the stories of past champions like Farmer are relatively well known, many other stories drawn from lower levels of the sport from all over Australia and the multiplicity of their football experiences remain largely unknown. This poses the question: What other stories are there of other players, their families, the clubs, and communities they came from? What have been the challenges they have faced over time and continue to face in contemporary sport loving Australia? It is only when questions like these are asked and the stories from around Australia gathered and subjected to scholarly analysis can the social and political importance of football in the lives of Aboriginal Australians be properly assessed. Anecdotal evidence suggests that community level football clubs have in many cases either operated (or acted) as quasi-kinship hubs and have been critical in cultural maintenance and social organization in Indigenous communities across Australia. As McCoy points out in his text Holding Men which looks at Kimberley desert communities, everyday life and football:

Both football and the law are highly valued expressions of male sociality ... [o]ne desert man, now a coach likened football to the social corroborees of the past where men gathered for social and recreational pleasure. 44

It is from these grass roots clubs and associations from regional, remote, and urban competitions that further Indigenous histories of Australian Football need to be more fully explored and contextualized. It is only through the development of such histories will the Australian public will come to understand the extent to which the national game has provided an important social, cultural, and political platform to organize and overcome adversity and alienation not just from an elite perspective but from 
regional, remote and urban sites and amateur competitions. Such histories are likewise critical in developing insights and more complex and informed understandings of broader issues that shape contemporary relations between Indigenous and non-Indigenous Australia including policies like 'National Reconciliation' and 'Closing the Gap'. What we are suggesting is that more research needs to occur in the Indigenous margins of football and its communities because it is here that so much more can be understood about Indigenous history and survival by doing so.

The reason this is suggested is many books to date have explored the history of Australian Football from the perspectives of past players, coaches, and administrators. Many of these have been autobiographical in nature and relied heavily on statistics focusing on detailed description of rivalries and significant games but have been largely devoid of any sociocultural or political analysis. Moreover, these histories have largely been written by Anglo-Australian men and have focused on the stories of other Anglo-Australian men in Australian Football. Despite this there is a small but growing body of literature that provides accounts of the significant and historic engagement of Aboriginal people with Australian Football over time.45

Given the contribution of Aboriginal peoples to the game of Australian football a much larger social, cultural, and political history has yet to be told, one that moves beyond mere journalistic description and nostalgia and significantly delves into the communities that these players have emerged from. A history that has a strong emphasis on Aboriginal people in football and is continental in scale, critical, rigorous, and scholarly and allows Aboriginal people to work collaboratively with specialist academics in telling it. A history that goes beyond the superficial focus of Aboriginal people's contribution to the elite AFL competition to provide a national history that acknowledges and documents the role Aboriginal peoples have played in shaping Australian Football nationally, regionally, and locally. Such a rich and dynamic national history is critically required to explore the various responses of the State and Territory leagues and associations to the Aboriginal teams, and people who have participated in them, and to chart the challenges that those teams and individuals were able to overcome and those that were not.

Another significant aspect of developing an Aboriginal history of the national game is the need to investigate and analyse specific clubs that were historically built and operated by Aboriginal people and/or had large cohorts of, or have been entirely made up of, Aboriginal players. Sadly the work that has been undertaken so far is at best scant and the published work around them is almost non-existent. This is a shame as there are many such clubs across Australia, each formed from a range of social and political circumstances and each with particular characteristics and modes of negotiating cross-cultural and racial politics and social relationships. Many of these All-Aboriginal teams and clubs have experienced a great 
deal of resistance from both the competitions in which they participated and the broader local community. Most had to work very hard to become successful and remain compliant and solvent in the leagues and associations in which they participated. Other clubs experienced the patronage of entire communities where Aboriginality and participation were celebrated only for the season to end and old 'settler' prejudices to come back, as Gorman recalls:

What I noticed during footy season was that Tambellup came alive ... The district's richest farmers and the town's business owners would all be talking and interacting with the youngest and wildest of the footy-playing Noongars ... The cricket season would slowly usher in the months and the Noongar season of Kambarang, effectively spring ... To me the sense of community that football seemed to foster had dried up ... In its place was indifference. 46

Some of these clubs have been merged with other clubs, while others have ceased to exist. Such clubs in Victoria include Lake Tyers, Coranderrk and Cummeragunja and, in more recent decades, the Purnim Bears. ${ }^{47}$ Successful clubs would include the Fitzroy Stars in inner Melbourne and Rumbalara in rural Victoria. In South Australia, 'Aboriginal' clubs include Point Macleay, Mallee Park, and Koonibba. In Western Australia, New Norcia, Tambellup, Mullewa, and The Wanderers are notable teams. In the Northern Territory, sides like St Mary's, Buffaloes, and South Alice Springs have unique and intriguing stories that are deeply entangled with the Aboriginal peoples of central Australia and the top end. ${ }^{48}$ The story of St Mary's football club in particular is one that is characterized by a deep and continuous Aboriginal involvement that has significant associations with the introduction and development of Catholic religious belief and the sport of Australian Football on the Tiwi Islands. Introduced to the Tiwi people in 1944 by Brother John Pye, competitions became consolidated in 1952.49 These developments coincided with the establishment of St Mary's football club in Darwin to create a safe recreational and social outlet for Tiwi workers. The role and function of St Mary's was incredibly important as it acted as a social incubator that later saw players like David Kantilla, Maurice Rioli, and Michael Long move to the southern states to play. ${ }^{50}$ All had major impacts on the development of the game at senior level. In this way, clubs become significant points for social interaction, political organization, and cultural engagement and have functioned as critical realms of survival and cultural revival and acted as important points of contact between Aboriginal and non-Aboriginal Australia.

Sport scholarship as it pertains to Indigenous Australian history can be hugely beneficial to exploring, uncovering, and documenting a side of Australia that has gone largely unacknowledged for too long. It seems logical that this commence with Australia's Indigenous game, Australian rules. Firstly, it should critically examine the national history of Aboriginal people in Australian Football for the first time. While there have been 
many different research projects, biographies, autobiographies, and individual club histories where Aboriginal peoples have played pivotal roles, none have addressed all of the aspects of those histories as well as the social, cultural, and political considerations from within a national context and delineated them. Further, opportunities exist for Aboriginal communities and experienced academics involved in a project of this scale to work collaboratively to create a nationally meaningful resource that can help strengthen and heal Aboriginal and non-Aboriginal communities alike. Such a project would help produce a long overdue addition to the Australian historical landscape in an approach that emphasizes Aboriginal people's perspectives. Collaborative partnership with those clubs, leagues, and associations would commence the telling of an Australian story that is of national significance and is long overdue.

What might such a project look like? By using a comprehensive combination of Aboriginal oral history, biography, autobiography, local history, social heritage, and memory it would provide a rigorous historical analysis of Australian football's black history by aiming to:

A Discover the common themes that may be derived from the study of specific leagu have had significant participation of Aboriginal players and determine what challenges succeed.

B Identify and analyze the key moments in football history in Australia of those Abori that are synonymous with the game but also those stories that have yet to be told.

C Analyze the context and the contribution Aboriginal peoples have made to Australi social, and political histories of the Australian nation state.

D Address issues of sustaining Aboriginal communities through better understanding ( in providing social cohesion in each community with emphasis placed on remote and $r_{1}$

This approach would highlight the social, cultural, and political commonalities and divergences as experienced by Aboriginal peoples and communities from urban, regional, and remote places and their relationship with the sport of Australian Football to provide new, critical, and culturally informed insights. This history would seek to tell these stories from the perspectives of the Aboriginal peoples and communities involved. In doing so the historical stories that emerge would rigorously detail and analyze a national and largely untold narrative of Australian Football that emphasizes and draws the attention of non-Indigenous people to the sociocultural meaning the sport has for Aboriginal peoples both in the past and in the present day. This is important because Australian Football plays an important societal role in Australian life. It is not just 'a sport' but a sociological, political, economic, and cultural phenomenon that highlights and celebrates Australian sporting life. It would allow Australian society, to grapple with difficult issues that engage with broader perspectives of national Australian history for both Aboriginal and non-Aboriginal Australians. ${ }^{51}$ 
Further to this, what is not as widely understood is the nationwide contribution that Aboriginal peoples have made historically to the growth and popularity of Australian Football. Such an understanding is both long overdue and important as it has enormous benefits to understanding Australian society more broadly, specifically notions of Aboriginal people's struggle, survival, and cultural and political renaissance through the Australian game of football. This history is particularly salient when it is conveyed through the narrative duality of newspapers, local history, and sporting histories on the one hand and the life stories of Aboriginal footballers, their families, extended kinship relationships and communities on the other. The envisaged research work would seek not just to close this gap in how the past is remembered but rather seeks to bridge the gap and in doing so provide new and valuable insights as well as reminders of why such divergent views of history developed and persist into the present day.

An investigation, comparison, and analysis of key moments and figures of Aboriginal football history from each State and Territory is a research priority. The project called for in this paper would seek to investigate Aboriginal participation in Australian Football that has occurred at the non-elite level and will therefore provide histories that are localized and that remain less well known. It will do this by looking at the clubs and the leagues (or associations) that these people have been affiliated with and the challenges and contexts that the individual/family/club have experienced. This research would also need to constitute a major nationally significant longitudinal study of (and with) Aboriginal peoples and would generate new knowledge, insights, and perspectives in the field of Australian Indigenous studies, Aboriginal history, Australian history, sport history, and the sociology of sport. This would result in new ideas and concepts about Australia, its people, and the importance of Australian Football in the national psyche for both Aboriginal and non-Aboriginal Australians alike. The research is necessary for providing the Australian Government and civil institutions with information that is directly applicable to informing how they might develop and maintain effective, mutually beneficial and sustainable relationships with Aboriginal peoples and their communities going into the future.

\section{Conclusion}

To conclude, we call for a black history of Australian football which, like the books First Australians (2008), First Footprints (2013), and Buried Country (2000) would be groundbreaking in providing a rich and detailed historical perspective of Aboriginal footballers, Aboriginal football families, and Aboriginal-run football clubs. In collaboration with Aboriginal people and experienced academics, the research required would enable a comparative reading to be made of the different eras and moments along with the sociopolitical importance of famous and lesserknown players to analyze specific challenges and success stories as they 
have arisen in Aboriginal football history. Through genuine community collaboration, this project would empower individual players, families, clubs, and leagues that have had high Aboriginal populations to tell their stories (and in many cases) for the first time to anyone other than their nuclear or extended kinship group. This is important in the interests of acknowledging intergenerational historical themes and the spirit of mutual respect and reconciliation. Ideally, a web-specific database would be a key feature in the telling of this history whereby all Australians would have access to specific, culturally approved data.

Perhaps the central challenge is that such research both demands and invites practitioners working in the Indigenous field to collaboratively incorporate Aboriginal people into their programmes and acknowledged them as full and equal participants in the way the history of the Australian national game is constructed, understood, told, and retold. This is a central tenet of Indigenous research methodologies globally, one with which sport historians have begun to engage. ${ }^{52}$ Through the 're-telling' of Australian football history, hopefully the challenge that W.E.H. Stanner, citied in the introduction, rings true.

\section{Notes on contributors}

Sean Gorman is a senior fellow in the School of Media Culture and Creative Arts, Curtin University. His book, Legends: The AFL Indigenous Team of the Century, was released in 2011.

Barry Judd is a professor of Indigenous Studies at RMIT University.

Keir Reeves is a professor of Australian History and foundation Director of the Collaborative Research Centre in Australian History in the Faculty of Education and Arts at Federation University Australia.

Gary Osmond is a senior lecturer in sport history in the School of Human Movement and Nutrition Sciences, University of Queensland. He co-authored Black and Proud: The Story of an Iconic AFL Photo with Matthew Klugman.

Matthew Klugman is an Australian Research Council DECRA fellow in the Sport in Society Research Program at the Institute of Sport, Exercise Science and Active Living, Victoria University.

Gavan McCarthy is an associate professor and a leader in cultural informatics at the University of Melbourne. He is expert in the building of sustainable information resources to support research.

\section{Notes}

1. W.E.H. Stanner, The Boyer Lectures 1968: After the Dreaming (Sydney: Australian Broadcasting Commission, 1969).

2. M. Sheahan, 'Mike Sheahan's Top 50: Cream of the Crop', in Geoff Slattery (ed.), The Australian Game of Football: Since 1858 (Melbourne: Geoff Slattery Publishing, 2008), 132; S. Hawke, Polly Farmer: A Biography 
(Fremantle: Fremantle Arts Centre Press, 1994); and S. Gorman, Legends: The AFL Indigenous Team of the Century (Canberra: Aboriginal Studies Press, 2011), 16-23.

3. Hawke, Polly Farmer.

4. A. Haebich, For Their Own Good: Aborigines and the Government in the South West (University of Western Australia Press, 1988); and S. Kinnane, Shadowlines (Fremantle: Fremantle Arts Centre Press 2003).

5. Hawke, Polly Farmer, 30.

6. Ibid.

7. Steve Kinnane, Judy Harrison, and Isabelle Reincke, 'Finger Money: The Black and White of Stolen Wages', Griffith Review 47 (2015), 49-70.

8. Leonie Sandercock and Ian Turner, Up Where, Cazaly? The Great Australian Game (Sydney: Granada, 1981), 220.

9. See, for example: Rob Hess and Bob Stewart (eds), More than a Game: An Unauthorised History of Australian Rules Football (Melbourne: Melbourne University Publishing, 1998); and Rob Hess et al., A National Game: The History of Australian Rules Football (Melbourne: Penguin, 2008).

10. M. Flanagan, The Call (Sydney: Allen and Unwin, 1998); Adam Goodes, 'The Indigenous Game: a Matter of Choice', in Geoff Slattery (ed.), in Geoff Slattery (ed.), The Australian Game of Football: Since 1858 (Melbourne: Geoff Slattery Publishing, 2008), 175-85; G. Hibbins, 'A Seductive Myth', in Geoff Slattery (ed.), The Australian Game of Football: Since 1858 (Melbourne: Geoff Slattery Publishing, 2008), 45; Barry Judd, On the Boundary Line: Colonial Identity in Football (Melbourne: Australian Scholarly Publishing, 2008); J. Poulter, Marn-Grook: Original Aussie Rules (Melbourne: J. Poulter, 2003); and G. de Moore, Tom Wills: His Spectacular Rise and Tragic Fall (Melbourne: Allen and Unwin, 2009).

11. G. de Moore, Tom Wills: His Spectacular Rise and Tragic Fall (Melbourne: Allen and Unwin, 2009); Judd, On the Boundary Line; Poulter, Marn-Grook; and G. Blainey, A Game of Our Own: The Origins of Australian Football (Melbourne: Information Australia, 1990).

12. Hibbins, 'A Seductive Myth'.

13. Poulter, Marn-Grook; Flanagan, The Call.

14. Hibbins, 'A Seductive Myth'.

15. Ciannon Cazaly, 'Off the Ball: Football's History Wars', Meanjin 67, no. 4 (2008), 82-7.

16. Barry Judd, meanjin.com.au/spike-the-meanjinblog/post/football-shistory-wars/ (accessed 17 June 2015).

17. J. Harms, 'Love of the Game: More than a Game', in Geoff Slattery (ed.), The Australian Game of Football: Since 1858 (Melbourne: Geoff Slattery Publishing, 2008), 98-100.

18. See C. Tatz, Obstacle Race: Aborigines in Sport (Sydney: University of New South Wales Press, 1995); Gorman, Legends; and B. Judd and T. Butcher, 'To Play Papunya: The Problematic Interface Between a Remote 
Aboriginal Community and the Organization of Australian Football in Central Australia', Sport in Society: Cultures, Commerce, Media, Politics (2014), 1-9.

19. D. Godwell, 'Playing the Game: Is Sport as Good for Race Relations as We'd Like to Think?', Australian Aboriginal Studies 1, no. 2 (2000), 3.

20. Ibid

21. Judd, On the Boundary Line; B. Judd, 'Joe Johnson: The First Aborigine in the VFL?', Journal of Australian Indigenous Issues, 8, no. 2 (2005), 31-9; Gorman, Legends; Matthew Klugman and Gary Osmond, Black and Proud: The Story of an Iconic AFL Photo (Sydney: NewSouth, 2013); Poulter, Marn-Grook; and B. Hearn Mackinnon, The Liam Jurrah Story: From Yuendumu to the MCG (Melbourne: Victory Books, 2011).

22. Gorman, Legends, 6.

23. Spectator, 'Champions of the Football Arena: Doug Nicholls: A Flying Aborigine', Argus, 21 June 1934, 7; Spectator, 'Popular Aboriginal Footballer: Doug Nicholls in the Pulpit', Argus, 12 September 1935, 7.

24. Haebich, For Their Own Good, 153-221.

25. Gorman, Legends, 95.

26. Anonymous, 'A Rare Character', Albany Advertiser, 24 June 1935, 4.

27. The Australian Abo Call, 1 April 1938, 2; Jane Lydon, The Flash of Recognition: Photography and the Emergence of Indigenous Rights (Sydney: NewSouth, 2012).

28. Australian Women's Weekly, 12 June 1957, 18-19; Bain Attwood and Andrew Markus, Thinking Black: William Cooper and the Australian Aborigines' League (Canberra: Aboriginal Studies Press, 2004), 10.

29. Australian Women's Weekly, 12 June 1957, 18-19.

30. T. Ruddell, 'The Story of an Origin Myth: Scotch College, Melbourne Grammar and Australian Football', Sporting Traditions XX: Old Stories, New Histories Conference Program (Darwin, Northern Territory, Australia, 30 June -3 July 2015).

31. T. Keneally, Australians: Eureka to the Diggers (Sydney: Allen and Unwin, 2011), 54.

32. Godwell, 'Playing the Game'; Tatz, Obstacle Race.

33. Godwell, 'Playing the Game', 4.

34. C. Wilson, 'Racism on the Field: AFL Football's Shameful Secret', Sunday Age, 25 August 1991.

35. S. Gorman, 'Blak Magik: Indigenous Identity and the Media in the 1980s', in P. Burke and J. Senyard (eds), Behind the Play: Football in Australia (Melbourne: Maribyrnong Press, 2008), 189-99.

36. G. Gardiner, "Levelling the Playing Field ...": Indigenous Footballers, Human Rights and the Australian Football League's Racial and Religious Vilification Code', in T. Taylor (ed.), How You Play The Game: The Contribution of Sport to the Promotion of Human Rights (Sydney: UTS, 1999), 152-58.

37. T. Ruddell, 'Albert "Pompey" Austin: The First Aborigine to Play Senior 
Football', in Peter Burke and June Senyard (eds), Behind the Play: Football in Australia (Melbourne: Maribyrnong Press, 2008).

38. Goodes, 'The Indigenous Game', 175-85.

39. Gorman, 'Blak Magik'.

40. Gorman, 'Blak Magik'.

41. Klugman and Osmond, Black and Proud.

42. Q. Beresford, G. Partington, and G. Gower, Reform and Resistance in Aboriginal Education (Perth: University of Western Australia Press, 2003); C. Tatz and P. Tatz, Black Gold: The Aboriginal and Islander Sports Hall of Fame (Canberra: Aboriginal Studies Press, 2000); and A. Haebich, Broken Circles: Fragmenting Indigenous Families, 1800-2000 (Fremantle: Fremantle Arts Centre Press, 2000).

43. Gorman, Legends.

44. B. McCoy, Holding Men: Kanyirninpa and the Health of Aboriginal Men (Canberra: Aboriginal Studies Press, 2008), 148.

45. Judd, On the Boundary Line; Klugman and Osmond, Black and Proud; Hawke, Polly Farmer; Poulter, Marn-Grook; McCoy, Holding Men; Tatz, Obstacle Race; G. Kingston, Black Crow: The Andrew McLeod Story (Sydney: Pan MacMillan, 2010); S. Gorman, Brotherboys: The Story of Jim and Phillip Krakouer (Melbourne: Allen and Unwin, 2005); and Gorman, Legends; Mckinnon, The Liam Jurrah Story; M. Flanagan, The Short Long Book: A Portrait of Micahel Long, the Man Who Changed the Australian Game (Melbourne: Random House Australia, 2015).

46. S. Gorman, 'A Whispering: Ask Not How Many; Ask Why Not', in Christian Ryan (ed.), Australia: Story of a Cricket Country. (Melbourne: Hardie Grant, 2011). 128-135.

47. D. Nadel, 'Aborigines and Australian Football: The Rise and Fall of the Purnim Bears', Sporting Traditions 9, no. 2 (1993), 23-35.

48. M. Stephen, Contact Zones: Sport and Race in the Northern Territory 1869-1953 (Darwin: Charles Darwin University Press, 2010).

49. J. Pye, The Tiwi Islands (Darwin: Colemans Printing, 1988).

50. Stephen, Contact Zones.

51. Tatz and Tatz, Black Gold; Gorman, Legends; Judd, On the Boundary Line; B. Judd, 'The Question of Indigenous Origins and the Unlevel Playing Fields: Outside the Boundary', in C.J. Hallinan and B. Judd (eds), Indigenous People, Race Relations and Australian Sport (London: Routledge, 2014); B. Judd, and C. Hallinan, 'Duelling Paradigms: Australian Aborigines, MarnGrook and Football Histories', in C.J. Hallinan and B. Judd (eds), Indigenous People, Race Relations and Australian Sport (London: Routledge, 2014); and Hess and Stewart, More than a Game, 61-72.

52. C. Bond, M.G. Phillips and G. Osmond, 'Crossing Lines: Sport History, Transformative Narratives and Aboriginal Australia', The International Journal of the History of Sport (2015). doi:10.1080/09523367.2015.1038704. 
